\title{
Formatting Online Image of "Halal" Destination through Photography
}

\section{Taufiqqurrachman}

School of Journalism, Information, and Communication, Huazhong University of Science and Technology, Wuhan, China Email: I201622042@Hust.edu.cn

How to cite this paper: Taufiqqurrachman (2020) Formatting Online Image of "Halal" Destination through Photography. Open Journal of Business and Management, 8, 660-682.

https://doi.org/10.4236/ojbm.2020.82040

Received: January 17, 2020

Accepted: March 7, 2020

Published: March 10, 2020

Copyright ( $) 2020$ by author(s) and Scientific Research Publishing Inc. This work is licensed under the Creative Commons Attribution International License (CC BY 4.0).

http://creativecommons.org/licenses/by/4.0/

(c) (i) Open Access

\begin{abstract}
Web 2.0 or social media as a digital instrument of the internet marketing is increasingly significant in formatting an online image of the tourist destination. The study collected photographic information of two destinations in Indonesia (West Sumatera and Aceh) from the official Instagram account of each of their local authorities to explore the online image of these destinations. Visual content analysis was applied to examine the image formation of this halal tourism within the collected photograph. The results indicate that various dimensions of an image are composed of five dimensions: social opportunity and attraction, natural and cultural amenities, accommodation and transportation, infrastructure, food and friendly people, physical amenities, and recreation activities. However, similarly natural and cultural amenities are the most emphasized dimension. Conversely, the dimension of accommodation and transportation is less stressed by these official webs. Meanwhile, categories of some image dimensions were emphasized differently. The implication of halal destination and study findings to the theoretical development of the image of halal tourism and some recommendations for future study were discussed.
\end{abstract}

\section{Keywords}

Tourism Image, Halal Destination, Image Formation, Public Tourism Organization, Visual Content Analysis

\section{Introduction}

The significance of the internet in tourism marketing has been well documented by some previous studies [1] [2] [3]. While, web site features and web site promotion techniques, and programs of customer relationship management are factors that influence the effectiveness of web marketing strategies [4], including 
consumer-controlled and advertiser-controlled aspects [5].

Meanwhile, Web 2.0, called social media or user-generated content media, is another instrument of tourism marketing. The scholar works show that social media is also crucial in destination marketing, as it influences destination selection [6] [7] [8] [9]. Mainly, Instagram is a social media platform used by tourism agencies to create the projected image of destination by producing and sharing pictures [10] [11].

The destination promotion is primarily aimed at projecting images of the destination to potential tourists, so it becomes desirable to them [12]. Image is tourist's idea, conception [13], and impression [12] [14] that comprise three interrelated components (cognitive, affective and conative) [15].

The image becomes an issue progressively highlighted by a researcher in tourism marketing studies. Some works demonstrate that image is vital in tourism marketing, as it affects tourist's destination selection [15], tourist satisfaction and destination loyalty [16], the length of stay in the destination [17]. Whereas, some other studies contributed empirical shreds of evidence demonstrating that the user's online media influence on their image formation [18] [19] [20] [21]. Likewise, other studies presented online media content created an image of destination [10] [11] [22] [23].

Whereas, "halal" tourism is a concept to refers to any product of tourism commercially created to provide hospitality services by Islamic beliefs and practices [24]. In recent years, government of several Islamic countries, including non-Islamic countries, for instance, Singapore, Japan, the United Kingdom, Germany, Australia) have been developing halal destinations. It is a rational choice by considering that halal tourism is a broad market niche. As the statistic shows in 2018, 140 millions of Muslim tourists participated in tourism activities, and in 2026, the number of Muslim travellers will reach 230 million [25].

Some geographical parts of Indonesia are widely known as halal destinations among global Muslim travellers. The survey placed Indonesia as the second-best Muslim-friendly destination among some other destinations of Muslim majority countries incorporated into OIC [25]. OIC (organization of Islamic cooperation) is an international organization consisting of 57 member states being Muslim majority countries.

Besides, mainly West Sumatera is awarded as World's best halal destination and World's best halal culinary. In contrast, Aceh is awarded as World's best halal cultural destination through World Halal Tourism Awards 2016 [26].

The photograph is essential in tourism marketing since it creates and communicated image [27] and promotes human value [28]. Indeed, some previous studies revealed projected images of some destinations were successfully created by photographs [11] [23] [27] [29] [30]. However, there is still minimal study examining photographs to deal with the issue of image formation within the context of halal destination promotion.

Even though, as demonstrated by previous studies, image is an essential issue 
in marketing tourism, since it influences on tourist's destination selection. Indeed, Akyol \& Kilinc [31] and Suradin [32] examined marketing web content to identify how halal destination is promoted. However, both studies highlighted various Islamic attributes emphasized in the selected marketing web content. Therefore, various image dimension conceptualized by scholars is still unexamined within the context of halal tourism marketing.

Government/public agencies is one element in destination marketing (branding) [33]. Additionally, the government in several countries adopt web marketing into their tourism marketing strategy [1]. This article study tried to fill this lacuna, particularly by examining how halal tourism image is projected visually by the public tourism agency through producing online photographs as their promotional materials posted on their official Instagram account. Focusing on two famous halal destinations of Indonesia (West Sumatera and Aceh), the study applied image theory developed by Fakeye \& Crompton [12] to understand how each of their public agencies creates the image of both destinations.

\section{Literature Review}

\subsection{Image Definition}

There are several image definitions conceptualized by scholars. Through reviews of tourism literature, Gallarza, Saura, \& García found 13 image definitions [34]. While Echtner \& Ritchie found 15 image definitions [35]. However, some scholars agreed that image is an impression [36], perception [37] [38], idea and conception on a destination [13] that reside in tourist mind.

According to Baloglu \& McCleary, the image consists of two elements: cognitive and affective [39]. The cognitive refers to knowledge and beliefs about a destination. In contrast, the affective element refers to feelings about a destination [40] or emotions that a tourist destination can evoke (e.g., pleasure, excitement] [41]. Gartner adds one more component in addition to the two components already mentioned earlier, conative, which refers to behaviour or tourist's action [15]. Dann [42], Pike \& Ryan [43], Agapito, Valle, \& Mendes [44], and Kim, Lee, Shin, \& Yang [20] agreed with this three-element of the image.

Some previous studies showed tourist's image formation was influenced by these elements [39], [45] as well as some other factors, such as motivation, experience gender, social class, the country of origin, source of information and social characteristics (age and education level of tourist) [46].

On the other hand, a source of information is an essential element in the process of image formation through which information is portrayed to the targeted tourists. It is as reflected through a definition of image formulated by Reynolds "the development of a mental construct based upon a few impressions chosen from a flood of information [14]". In this context, Fodness \& Murray introduced two categories of the source of information: commercial and non-commercial [47]. 
Two categories of image developed by Gunn: organic and induced image likely is also reflected the differences of media, which take part in image formation [48]. The author explained that the organic image is created by the non-touristic source of information consisting of News reports, magazines, books, movies), education (school courses), and the opinions of family/friends. In contrast, the induced image is formatted by the commercial source of information. Travel brochures, travel agents, and travel guidebooks were included in the last category of the source of information.

Further, Gartner added some other image categories created by the differences in the source of information [15]. For instance, solicited organic image is created through word-of-mouth advertising, while Overt Induced one image by the agent of traditional forms of advertising by using several media, such as television, radio, brochures, billboards, and print media advertising.

Besides, Gunn's image categories (organic and induced image), the projected image, and re-evaluated image were introduced by Selby \& Morgan [49]. He defined the first as the image created by the official destination organization, while tourist itself creates the last through destination visitation. Therefore, the re-evaluated image is similar to the complex image, as theorized by Fakeye \& Crompton, a kind of image created by tourists after his destination visitation [12].

Meanwhile, various image dimensions were conceptualized to deal with the issue of image formation by some other scholars, such as Gearing, Swart, \& Var [50], Pearce [51], Dilley [52], Gartner [53], Fakeye \& Crompton [12], Lian $\& \mathrm{Yu}$ [23]. All image dimensions developed by those scholars are presented in Table 1.

\subsection{Researches on the Tourism Web Marketing and Image Formation}

Several forms of media are vital in image formation, such as visual and written content of movies, guidebooks and magazines [54]; film [55], and [56]; mass media [57]; TV news, travel documentaries, news report, and the internet [21].

Internet is another form of media integrated into the tourism marketing strategy. Gertner, Berger, \& Gertner revealed that country portal with country name-dot-com has contributed to country branding development as well as synergizing all activities, such as investment, product offerings, and services [1]. Since the portal with country name-dot-com domain could be accessed easily by users.

Also, the study of Nusair indicated that e-commerce web sites successfully develop e-relationship through reinforcement of two categories of customers' commitment (calculative dan effective) [3]. The commitment reinforcement is measured by the quality of alternatives, investment size, satisfaction, and trust. Kuster showed a similar finding that the internet is a relational tool to improve the relationship between the travel company and its customers [2]. 
Table 1. Image factors are taken from several pieces of literature of tourism.

\begin{tabular}{|c|c|c|}
\hline No & Author & Image Attributes \\
\hline \multirow[t]{5}{*}{1} & Gearing, Swart, Turgut [50] & Natural factor \\
\hline & & Social factor \\
\hline & & Historical factor \\
\hline & & Recreational and shopping facilities \\
\hline & & Infrastructure and food and shelter \\
\hline \multirow[t]{13}{*}{2} & Pearce [51] & Cheap shopping \\
\hline & & Adventure holiday \\
\hline & & Contact with local peasant people \\
\hline & & Exotic local custom \\
\hline & & Interesting tourist sight \\
\hline & & Spectacular scenery \\
\hline & & Appealing food \\
\hline & & Swinging social life \\
\hline & & Absence from other tourists \\
\hline & & Good sun and beaches \\
\hline & & Good winter \\
\hline & & Interesting politics and society \\
\hline & & Strong personal attraction \\
\hline \multirow[t]{4}{*}{3} & Dilley [52] & Landscape \\
\hline & & Culture \\
\hline & & Recreation \\
\hline & & Services \\
\hline \multirow[t]{4}{*}{4} & Gartner [53] & Out-group social \\
\hline & & In-group social \\
\hline & & Cultural based \\
\hline & & Natural resource-based \\
\hline \multirow[t]{6}{*}{5} & Fakeye and Crompton [12] & Social opportunities and attractions \\
\hline & & Natural and cultural amenities \\
\hline & & Accommodations and transportation \\
\hline & & Infrastructure, foods and friendly people \\
\hline & & Physical amenities and recreation activities \\
\hline & & Bars and evening entertainment \\
\hline \multirow[t]{3}{*}{6} & Lian and $\mathrm{Yu}[23]$ & Tourism facilities \\
\hline & & Tourism services \\
\hline & & Tourism resources \\
\hline
\end{tabular}


Wang \& Fesenmaier suggested several factors are needed for the effectiveness of web marketing strategy (Web site features, Web site promotion techniques, and CRM programs) [4]. Meanwhile, Mills \& Douglas proposed the model of Modified Interactive Tourism Advertising. The model describes that the effectiveness of web advertising is affected by consumer-controlled and advertiser-controlled dimensions [5].

At the same time, after Web 1.0, web technology continues to develop and successfully generate Web 2.0. To Aghaei, Nematbakhsh \& Farsani, the second generation of Web is characterized by connected users by adopting participative, community, and read-write interface and bi-directional approaches, meanwhile, web 1.0 tend to emphasize informational relationship [58]. The author added that the first generation of the web is characterized by mono-directional, static, and read-only approaches.

Recently, Web 2.0 takes a role to mediate tourism activities as credible and trustworthy information [59] that influence tourist's trip planning [60] [61]. On the other side, the tourism industry integrates social media into their marketing strategy [62]. Some scholarly work demonstrated that social media is significance in destination marketing as influence destination selection [6] [7] [8] [9].

Other group studies examined the relationship between online media usage and destination image formation. For instance, the work of Dwivedi demonstrated that tourist's image formation is affected by their activity of online information searching, then the image is shared via the internet [18]. A similar finding is shown by Li, Pan, Zhang, \& Smith that tourist's online information search contributed effect to their overall and affective image [19]. Likewise, Kim et al. presented content cues of tourism information in social media (Sina Weibo) affected the cognitive or affective image of Chinese tourists [20].

Meanwhile, online content, both visual and textual, was proven empirically to represent the image of the destination. Pavlović \& Belullo [63] and Lian \& Yu [23] studied contents of various category online resources, such as the official tourism website of Istria, tour operators and travel agents' websites, online travel magazine and guide websites, and online travel blogs. Those authors found differences in media represented the differences in the projected image.

For instance, Pavlović \& Belullo found that recreational facilities and rich Mediterranean heritage are these prominent destination attributes in the content of official Istrian County Tourism Office (ICTO) website. Whereas, beaches, nature are those who were prominent in Guide, blogs, and travel trade. The last, Istria, with its locality dimension, for instance: the image of local people, wine, music, and island, were more prominent in the magazine [63].

Then, Lian \& Yu by applying three destination attributes (tourism resources, tourism facilities, and tourism services), revealed shreds of evidence demonstrating that official online media preferred to demonstrate tourism resources, then tourism facilities, but hardly demonstrated any information of tourism services. However, to some extent, online tourism marketers tended to present the 
information of tourism resources, tourism facilities, and tourism services [23].

\section{Methods}

The West Sumatera and Aceh are the provincial region of Indonesia located geographically in the Sumatera Island. Mainly, The West Sumatera is located in the centre part of Sumatera island, whereas Aceh occupies the western end of the island. Recently, both local authorities of the province have been developing their destination by the concept of halal tourism. The geographical position of those provincial regions is presented in Figure 1.

Battour \& Ismail define halal as permissible practices allowed by the Islamic teachings [64]. While, in the dictionary of Leisure, Travel, and Tourism, the term of tourism is defined as the business of providing travel, accommodation, food, entertainment for tourists [65]. Accordingly, the concept of halal tourism may be viewed merely as a business that supplies various kinds of services or products, such as food, accommodation, travel, which are allowed by Islamic teachings. It is in line with what Ahmed \& Akbaba said that halal tourism refers to the product of tourism created to provide hospitality services following Islamic beliefs and practices [24].

Halal tourism grows as a promising niche market, as statistic showed in 2018, 140 millions of Muslim tourists participated in tourism activities. It is forecasted that in 2026, the number of Muslim travellers will reach 230 million [25]. Seven factors were identified to encourage the growth of the global market of the halal tourism market, such as growing Muslim population, growing middle class, younger population, increasing access to travel information, increasing availability of Muslim-friendly travel services and facilities, Ramadhan travel, business travel [25].

In general, Indonesia destinations are globally-known as Muslim friendly destinations among Muslim travellers. In 2019, the Indonesia destinations ranked 2nd under those of Malaysia as the best Muslim destinations [25]. Besides, Indonesia won 12 categories of the 2016 halal tourism award held in Abudhabi. Mainly, the West Sumatra won two categories: the world's best halal destination and World's best halal culinary, while Aceh won the category of the World's best halal cultural destination [26].

Recently, each local authority takes part in promoting its halal destination through web marketing. Hundreds of photographs are produced and posted on that official web. Besides, the photos are reposted on their official accounts of several social media platforms (Facebook, Twitter, Youtube, and Instagram). Their website address and official Instagram account are presented in Table 2.

The photograph is a crucial promotional material for creating and communicating destination image [27] attracting tourist and stimulating a behavioural intention [66], and improving destination image [11]. Several previous studies presented photograph in the touristic media represented the image of destination [22] [23] [29] [30] [67]. 


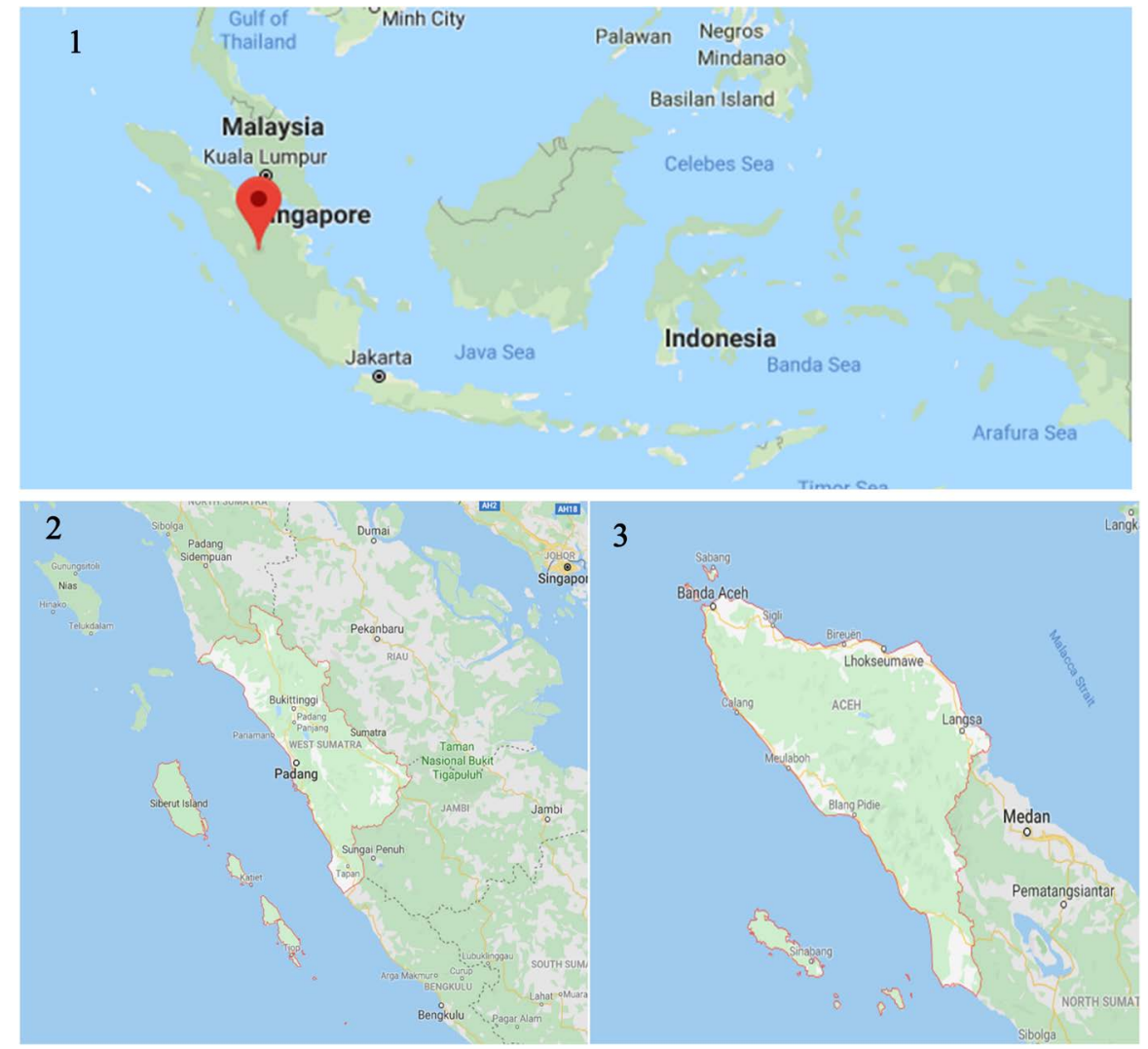

Figure 1. Indonesia map (1); The West Sumatera map (2); The Aceh map (3).

Table 2. The selected official Instagram account and the amount of selected data.

\begin{tabular}{ccc}
\hline Instagram account name & $\begin{array}{c}\text { Amount of the } \\
\text { posted photograph }\end{array}$ & $\begin{array}{c}\text { Amount of the } \\
\text { selected photograph }\end{array}$ \\
\hline Sumbartravel & 624 & 393 \\
Acehtourism.travel & 272 & 221 \\
\hline
\end{tabular}

At the same time, public agency or government is an element of tourism marketing [33]. Several public agencies of tourism marketing have integrated web marketing into their branding strategy by which the county-name-com domain is used to reach the global audience [1].

The article highlighted how the image of two halal destinations in Indonesia is created by their local authorities (West Sumatera and Aceh) through which photographs were produced and posted in their official Instagram accounts. The photograph as the study data were taken manually from their official account by using a feature of the screenshot. A feature is available commonly in various electronic devices (laptop, computer desktop, smartphone, tablet). The process of taking photos on the two official websites is carried out in approximately two months, from 05 August to 30 September 2019. Therefore, any photo posted on those websites after the expiration time of data retrieval was not covered by the study.

All photos are analyzed to ascertain whether they are relevant to the issue ad- 
dressed by the study. Then, each photo was registered by giving them a number and listed into a table. The amount of the selected photos derived from two official websites were presented in Table 2. Then, a visual content analysis was applied to analyze the selected photographs. Content analysis may be briefly defined as the systematic, objective, quantitative analysis of message characteristics [68]. The message as object analysis may be visual, verbal graphic, oral-indeed, any kind of meaningful visual/verbal information [69].

Notably, in the photo analysis, a classification scheme is formulated to measure the photographs [29]. He added the measurements might include the frequency with which particular subjects occur, the dominant colours and compositions, the distribution of particular poses or landscapes, and clusters of particular photographic techniques. In this case of study, the appearance of a particular subject in the photograph was measured and compared.

The six dimensions of image developed by Fakeye \& Crompton (social opportunities and attraction, natural and cultural amenities, accommodation and transportation, infrastructure, food and friendly people, physical amenities and recreation activities, and nightlife and entertain) were applied to analyze how those photos create the destination image [12]. In the study, all selected photographs were coded to calculate and compare the appearance of a certain subject or attribute in the photo. Atlas.Ti, a software application for qualitative data analysis, is used for coding each photo. For a description of image dimensions and coding guidance, see Table 3.

\section{Result}

Table 4 presents the frequency of occurrence for each dimension of the image in the photograph derived from official websites of both public agencies. Generally,

Table 3. Description of image dimension, adopted from (Fakeye \& Crompton, 1991).

\begin{tabular}{|c|c|}
\hline Image dimension & Description \\
\hline $\begin{array}{l}\text { Social opportunities and } \\
\text { attraction (SOA) }\end{array}$ & $\begin{array}{l}\text { SOA refers to tourist involvement in the touristic event. Several categories } \\
\text { were attributed to this dimension festival, cultural performance, music } \\
\text { concert, some other cultural events. }\end{array}$ \\
\hline $\begin{array}{l}\text { Natural and cultural } \\
\text { amenities (NCA) }\end{array}$ & $\begin{array}{l}\text { NCA refers to two categories of attraction offered for tourists (nature and } \\
\text { culture). Natural attraction covers some elements, such as mountains, } \\
\text { beaches, lakes, coastal. Second, cultural attraction consists of historical } \\
\text { buildings, cultural heritage, cultural performance, museums. }\end{array}$ \\
\hline $\begin{array}{l}\text { Accommodation and } \\
\text { transportation (AT) }\end{array}$ & $\begin{array}{l}\text { Any depiction of a hotel, apartment, condominium, villa and various } \\
\text { forms of transportation service, such as a ship, bus, airplane, airport, } \\
\text { seaport was coded as AT. }\end{array}$ \\
\hline $\begin{array}{l}\text { Infrastructure, food and } \\
\text { friendly people (IFFP) }\end{array}$ & $\begin{array}{l}\text { Infrastructure refers to the work system of the state required of tourism } \\
\text { activity. Food and friendly people are the unique experiences offered for } \\
\text { tourists while purchasing a destination. }\end{array}$ \\
\hline $\begin{array}{l}\text { Physical amenities and } \\
\text { recreation activities } \\
\text { (PARA) }\end{array}$ & $\begin{array}{l}\text { PARA refers to any physical comforts and touristic activities as a part of } \\
\text { touristic attraction. }\end{array}$ \\
\hline
\end{tabular}


Table 4. Photo distribution into highlighted image dimensions.

\begin{tabular}{|c|c|c|}
\hline Photograph depicting & The West Sumatera & Aceh \\
\hline \multicolumn{3}{|c|}{ Social opportunity and attraction } \\
\hline Concert & 7 & \\
\hline Festival & 55 & 50 \\
\hline Contest & 5 & 1 \\
\hline Sport event & 87 & 4 \\
\hline Religious event & 5 & 5 \\
\hline Sub-amount & 159 & 60 \\
\hline \multicolumn{3}{|c|}{ Natural and cultural amenities } \\
\hline Beach & 17 & 19 \\
\hline Park & 10 & 2 \\
\hline canyon & 4 & 0 \\
\hline cave & 4 & 1 \\
\hline Cultural heritage & 24 & 3 \\
\hline Cultural performance & 48 & 16 \\
\hline Forest & 1 & 1 \\
\hline Historical site & 10 & 10 \\
\hline Lake & 7 & 5 \\
\hline Local daily life & 0 & 11 \\
\hline Monument & 3 & 2 \\
\hline Mosque building & 20 & 17 \\
\hline Mountain & 2 & 3 \\
\hline Museum & 1 & 7 \\
\hline Natural/green scenery & 55 & 15 \\
\hline Rice fields & 1 & 0 \\
\hline River & 1 & 2 \\
\hline Treehouse & 2 & 0 \\
\hline Valley & 4 & 0 \\
\hline Waterfall & 0 & 6 \\
\hline Sub-total & 166 & 94 \\
\hline \multicolumn{3}{|c|}{ Accommodation and transportation } \\
\hline Boat & 2 & 1 \\
\hline Train & 1 & 0 \\
\hline Ship & 1 & 0 \\
\hline Airport & 2 & 0 \\
\hline Seaport & 0 & 2 \\
\hline Sub-total & 6 & 3 \\
\hline
\end{tabular}




\section{Continued}

Infrastructure, food and friendly people

$\begin{array}{ccc}\text { Café } & 1 & 0 \\ \text { Friendly people } & 15 & 3 \\ \text { Food } & 22 & 27 \\ \text { Food market } & 0 & 2 \\ \text { Good highways } & 9 & 0 \\ \text { Shopping center } & 0 & 1 \\ \text { Sub-total } & 47 & 33\end{array}$

Physical amenities and recreation activities

A wide variety of recreation activity

Ride a hinging bicycle

Surfing

Hang out

33

eligious activities

Sub-total

$11 \quad 25$

10

120

110

126

$15 \quad 31$

they emphasized more dimension of natural and cultural amenities (NCA) than that of social opportunity and attraction as well as other dimensions, as the total amount of appearance of some categories included into NCA are higher than those of other dimensions. Vice versa, similarly, both agencies less emphasized the dimension of accommodation and transportation (AT). Firstly, It is indicated by a few categories of AT promoted through their photograph production (Particularly Aceh only appeared two categories: boat and seaport); secondly, low rate of occurrence of those categories.

However, the differences in image categories of each dimension were highlighted by those agencies. First, for the dimension of Social opportunities and attraction, West Sumatera agency portrayed sports events prominently, such as race bikes, crossed motorbikes, horse racing. Additionally, a special event is emphasized by portraying several kinds of the festival (music concerts, photo contests). However, the last image categories were not promoted remarkably. Also, the Aceh tourism agency is more likely to picture various kinds of festivals (cooking competition, cultural festival). It was indicated by the highest amount of occurrence numbers reached by that image category. Also, sports events were pictured in Aceh; however, its occurrence number is less significant. Notably, the category of a concert is not pictured in Aceh.

Second, for the dimension of natural and cultural amenities, various categories were promoted by those official accounts, such as beach, forest, waterfall, mountain, lake, canyon, valley. Mainly West Sumatera agency more likely to picture green scenery and cultural performance since those categories occurred dominantly in its photos. Through the category of green scenery, the natural 
beauty of West Sumatera nature is portrayed, as if offered to users for consumption. In contrast, the category of cultural performance depicted local people wearing their traditional dress and performing local arts or dance.

Mosque building and cultural heritage are two other categories highlighted in the official account of West Sumatera agency, as Aceh webs did, mainly mosque buildings. However, especially for natural amenities, Aceh emphasized the beach. It is different from West Sumatera, which stresses more green scenery, as presented earlier.

Third, accommodation and transportation (AT) were likely not accented by those official webs, since only a few categories were pictured with the less significance of occurrence number. In the West Sumatera agency, four categories of AT were portrayed. Two of them (boat and airport) appeared (2 times), while the rest only one time (train and ship). Even in the official account of Aceh tourism, as presented earlier, only two categories were pictured (boat and seaport). Also, they appeared less significantly in the data.

Fourth, the official web of West Sumatera and Aceh emphasized similarly local food in their visual promotional materials, as one category in IFP appeared prominently in the data. Friendly people, good highways, and café are other categories promoted by the official web of west Sumatera, while the Aceh account promoted friendly people, food market, and shopping centre. Finally, several recreation activities were depicted by both official accounts, such as ride a hinging bike, hang out, surfing, however not emphasized remarkably, as their frequency of appearance was low. Meanwhile, several religious activities were portrayed, such as pilgrimage, praying at the mosque, reciting the Qur'an, and so on. Finally, some image categories depicted prominently by the two official Instagram account are presented in Figure 2 and Figure 3.

\section{Discussion}

Ingold defines culture as a human capacity manifested in various forms, for instance, the artefact (material culture), ritual, belief, art, dance, and music [70]. At the same time, culture is closely related to advertising or marketing, as some various studies demonstrate that advertisings promote various cultural values [71] [72] [73]. Particularly in the tourism marketing context, a study of Mok \& Defranco presents the cultural value of Chinese tourists influence on their tourism practices covering the process of travel decision making and their touristic behaviour while visiting or consuming the destination [74].

Besides, human value is embedded in the concept of the brand [75]. Empirically, work of Saji, Vij, \& Kabiraj demonstrates that the tourist' human value affect their destination purchasing [76]. The study's findings certainly have implications for tourism marketing, as presented by the study of Taufiqqurrachman that photographs as promotional materials of Bali destination derived from several official Instagram account of tourism marketing agency promote human values [28]. Accordingly, several depictions of objects (destination, people (host 


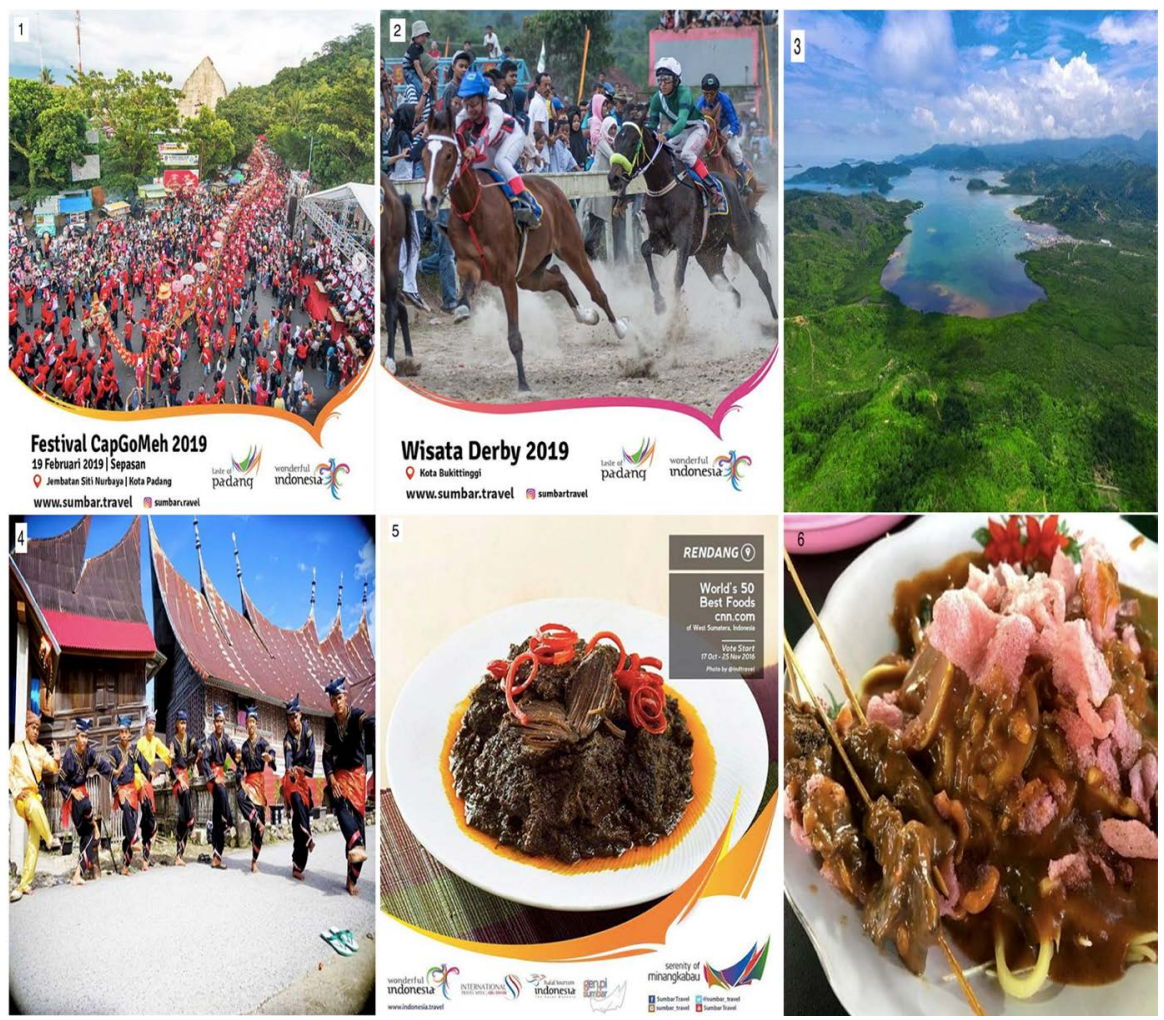

Figure 2. Some prominent image categories depicted in the official account of West Sumatera tourism agency: festival events ((1) \& (2)), beach (3), mosque building (4), local foods ((5) \& (6)).
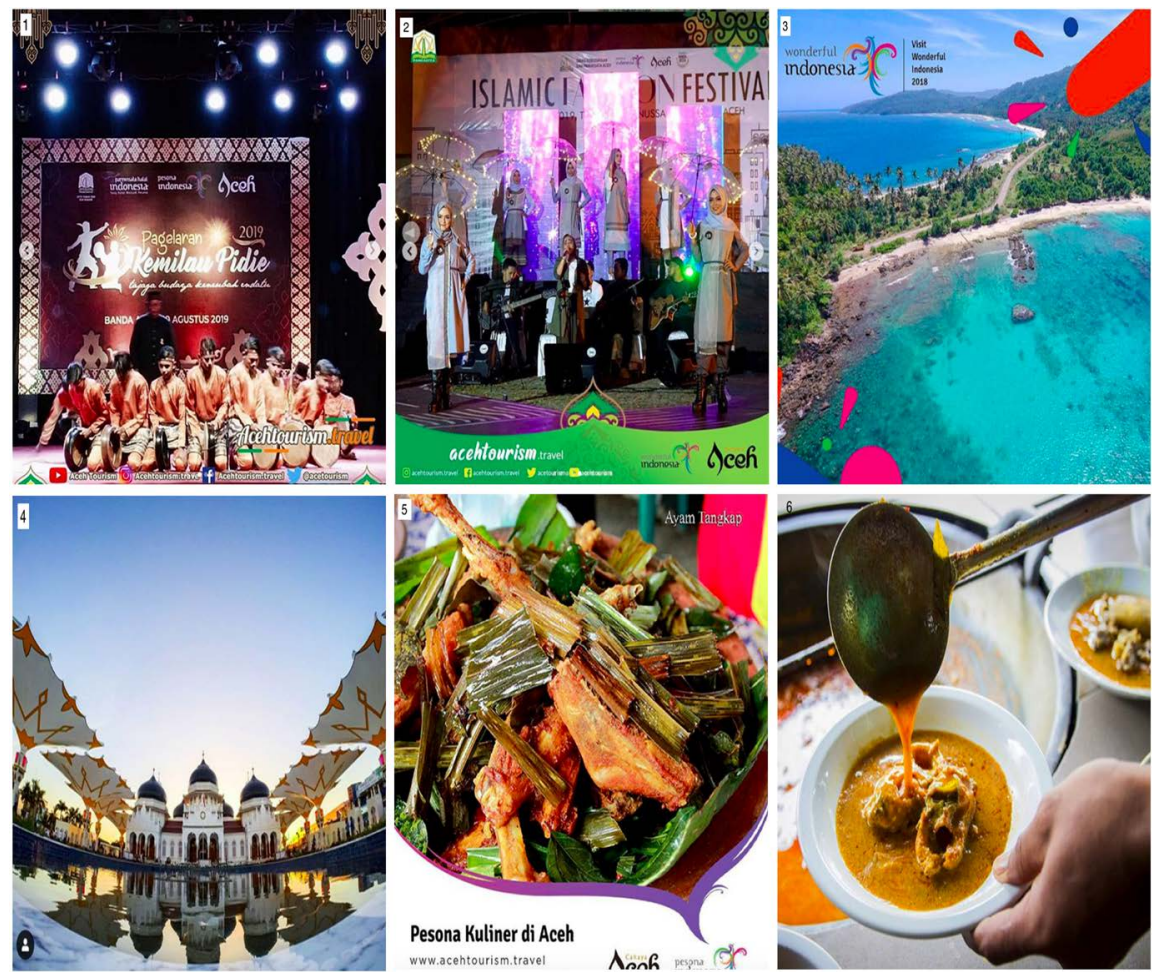

Figure 3. Some prominent image categories depicted in the official account of Aceh tourism agency: festival events ((1) \& (2)), beach (3), mosque building (4), local foods ((5) \& (6)). 
and tourist), tourism amenities/services) found in the study may represent both cultural and human value. Future research is recommended to deal with the issue in the particular context of halal tourism marketing.

Nevertheless, these study findings can be seen in the perspective of halal tourism. As conceptualized by Ahmed \& Akbaba, halal tourism is produced to provide Muslim tourist needs while visiting a specific destination [24]. Also, Battour, Battor, \& Bhatti confirmed that the availability of mosques is one attribute of halal tourism [77]. From this perspective, the depiction of mosque buildings in several photos is a way to fulfill the halal tourism attributes.

In the study, the religious event is a category included in the dimension of SOA since it is viewed as a social opportunity provided for tourists. By depicting these events, tourists are invited to participate and feel a different experience when interacting with other tourists in the event. In contrast, religious activities are included in the dimension of physical amenities and recreation activities. Somehow, the photo is one of the promotional materials; therefore, various religious activities pictured in specific photos may be viewed as an attraction in the form of physical activities provided for tourists to enjoy their pleasure.

Finally, in the study, the mosque building is a category included in the dimension of NCA. On the one hand, within the context of touristic image formation, the depiction of mosque building could be coded as a historical site. It is following Gearing et al. explain that this historic image site is characterized by the depiction of some elements, such as ancient ruins, religious significance, and historical prominence [50]. Indeed, these three elements are circulated in the photo when depicting several mosque buildings, as shown in Figure 4.

Additionally, the atmosphere of Muslim friendly destinations also is reinforced by depictions of Muslim fashion festivals and women in hijab (typical Muslim women dress covering their head). Mainly in the account of the Aceh tourism agency, several photos found depicting the various events of Muslim fashion festivals.

Bars and evening entertainment are other dimensions of the image destination [12]. Nighttime recreation is similar to that dimension found in the work of Gearing et al. [50]. Some categories (gambling casinos, discotheques, cinema, theatres) are attributed to that dimension by the author. However, none of the photo derived from both official tourism agency promotes these image categories. This finding is in line with El-Gohary clarifying halal tourism requires no nightclubs or nighttime entertainment [78]. Along with this, some activities closely associated with nightlife do not meet the criteria of halal tourism, such as consuming drinks containing alcohol [78], gambling games [79].

However, the contradiction finding is shown in this study. On the one hand, the Islamic atmosphere was created by describing religious events, religious practices, women in hijab, mosque buildings, including no depiction of nighttime entertainment. However, on the other hand, when both official accounts emphasize food as one of their attractions, no photo highlights the halal 

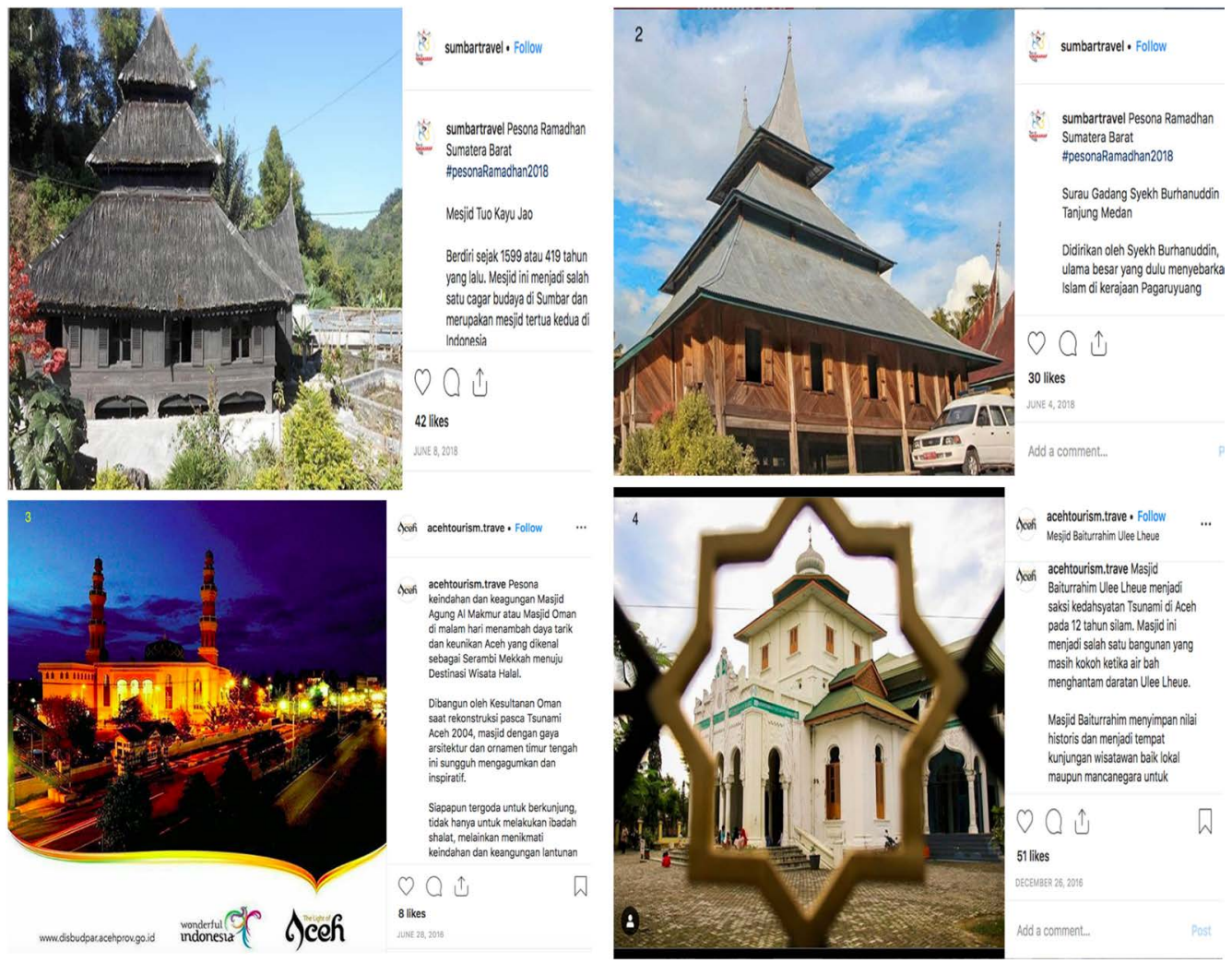

Figure 4. Two mosque buildings emphasizing the aspect of their old architecture building are taken from the West Sumatera tourism account ((1) \& (2)), two others emphasizing their historical aspect as represented through the photo captions are taken from the Aceh tourism account ((3) \& (4)).

aspects of the food. For instance, the halal logo accompanying the highlighted food is no depicted. Halal food is one indicator to measure the level of a Muslim-friendly destination [25]. Also, halal food availability is one of the attributes that directly impact tourist satisfaction [79].

Indeed, there are none of the photos that depict foods containing pork, alcohol, but it does not mean the foods they describe have met halal standards. Since Hanzaee \& Ramezani describe the product of halal food need to fulfill two aspects: first, the product does not contain pork or its byproduct, alcohol, prohibited food ingredients of animal origin, and prepared and manufactured on clean equipment. Second, the food product has been certified as halal product shown by the halal certificate and the halal logo issued by an Islamic organization [80].

By visual content analysis toward photographs posted on two official Instagram accounts successfully identify some dimensions of the projected image of two halal destinations in Indonesia: West Sumatera and Aceh. At the same time, the study contributed to the development of destination image theory in general; and six factors of image dimension conceptualized by Fakeye \& Crompton in particular [12]. Principally, halal tourism is also a tourism product created for commercial purposes like other destinations. However, Muslim tourist is the main target for the marketing of this kind of destination. Therefore, for tourism 
marketing, mainly through the creation of the projected-image, the marketer needs to convert various Muslim needs and attractiveness into elements of an image, such as four elements found by the study (religious event, religious activities, mosque buildings, women in hijab).

Besides, some recommendation is provided by the study. First, different audiences, time, and situation, create polysemic meanings of advertising [81] as well as a photographic image [82]. Semiotic analysis is recommended to deal with that issue since Rose argues the method of analysis provides an analytical tool uncovers the different levels of meaning communicated by a photo [83].

Second, different stakeholders (commercial and public) take part in marketing the destination. The study only covers visual materials of tourism marketing produced by public agencies of two halal destinations. Therefore, the future study needs to expand the scope of the study by covering promotional materials produced by the different agencies to gain a holistic understanding of the creation of a halal destination image. Besides, the notion of the 'circle of representation' conceptualized by Jenkin described that tourism organizations and tourists format images. The study provided empirical findings on the projected-image of halal destination. Therefore, future research needs to question how tourist creates the perceived-image of halal destination.

Third, various image dimensions conceptualized by some scholarly studies; however, they have been summarized by Lian \& Yu into three dimensions (tourism facilities, tourism services, tourism resources] [23]. The two agencies did not cover these image dimensions proportionally since they emphasized more tourism resources dimension, for instance, natural and cultural amenities and social opportunity. At the same time, some other dimensions are not highlighted (accommodation), as no photo depicts accommodation services (hotel, apartment, villa).

\section{Conclusions}

This study collects photographs from the official Instagram account of West Sumatera and Aceh tourism authority to identify how they project the image of their destination as halal tourism through photograph production. Qualitative visual content analysis is adopted to explore the various dimensions of the online image, and further investigate the distribution of each dimension in the selected photographs taken from both official webs. The online images of both halal destinations are explored from five dimensions of image conceptualized by Fakeye \& Crompton (social opportunity and attraction, natural and cultural amenities, accommodation and transportation, infrastructure, food, and friendly people, physical amenities and recreation activities, and nightlife and entertainment) [12].

This research figures out the similarities of images emphasized by different official webs. The official account of West Sumatera and Aceh's authority stressed more dimensions of natural and cultural amenities than other dimen- 
sions. Besides, both of them less stressed the dimension of accommodation and transportation. However, they highlighted some categories of each dimension differently. In the dimension of NCA, green scenery and cultural performance are highlighted in the West Sumatera authority account, while beach and mosque building is accentuated in Aceh authority account. Some studies confirmed that that scenery is a factor to increase destination attractiveness [84] [85] [86] [87]. Therefore, the prominence of green scenery in the visual content of official West Sumatera account supports those previous studies. Likewise, "beach" depicted remarkably in that of official Aceh tourism account is in line with the work of Pearce [51].

Dilley theorizes culture as the dimension of destination image that covers various elements (local history, art, and architecture, remains of an earlier civilization, old buildings, castles, museums, and art galleries, illustrations of local economic life) [52]. Similarly, the importance of culture within the context of destination image formation is found by various studies: exotic local custom [51], architecture/buildings, historical sites/museums [50] [35] [30], cultural sites [85]. The study results also support the previous study findings by which some categories of the theme of culture are highlighted, such as cultural performance, mosque building, and local daily life.

Both official authority accounts also represent different categories of SOA remarkably. Sports events are the most stressed category in the account of West Sumatera, while some festival events are underlined in the account of Aceh. Gearing et al. (1974) included these two categories into the social factor of image formation [50]. These study findings are in line with Echtner \& Ritchie [35] and $\mathrm{Hu} \&$ Ritchie [85] presenting that various festival events, including sports events and competition, are elements of destination attractiveness.

Additionally, food is more underlined by both official accounts than other categories distributed in the theme of IFP. Some scholars conceptualize food as the attractiveness of destination [35] [50] [85]. In line with this, some other studies notably showed the importance of local food in tourism [88] [89]. Meanwhile, the World Wide Web (WWW) also is used for food tourism marketing (Kim, Yuan, Goh, \& Antun, 2009) [90]. Therefore, the prominent depiction of various local foods in both official accounts supports those previous studies.

\section{Conflicts of Interest}

The author declares no conflicts of interest regarding the publication of this paper.

\section{References}

[1] Gertner, R.K., Berger, K.A. and Gertner, D. (2007) Country-Dot-Com. Journal of Travel and Tourism Marketing, 21, 105-116. https://doi.org/10.1300/J073v21n02_08

[2] Küster, I. (2006) Relational Content of Travel and Tourism Websites. Asia Pacific Journal of Tourism Research, 11, 119-133.

https://doi.org/10.1080/10941660600727467 
[3] Nusair, K.K., Hua, N. and Li, X. (2010) A Conceptual Framework of Relationship Commitment: E-Travel Agencies. Journal of Hospitality and Tourism Technology, 1, 106-120. https://doi.org/10.1108/17579881011065029

[4] Wang, Y. and Fesenmaier, D.R. (2006) Identifying the Success Factors of Web-Based Marketing Strategy: An Investigation of Convention and Visitors Bureaus in The United States. Journal of Travel Research, 44, 239-249. https://doi.org/10.1177/0047287505279007

[5] Mills, J.E., Lee, J.K. and Douglas, A.C. (2007) Exploring Perceptions of US State Tourism Organizations' Web Advertising Effectiveness. Asia Pacific Journal of Tourism Research, 12, 245-266. https://doi.org/10.1080/10941660701416820

[6] Schmallegger, D. and Carson, D. (2008) Blogs in Tourism: Changing Approaches to Information Exchange. Journal of Vacation Marketing, 14, 99-110. https://doi.org/10.1177/1356766707087519

[7] Xiang, Z. and Gretzel, U. (2010) Role of Social Media in Online Travel Information Search. Tourism Management, 31, 179-188.

https://doi.org/10.1016/j.tourman.2009.02.016

[8] Parra-López, E., Bulchand-Gidumal, J., Gutierezze-Tano, D. and Díaz-Armas, R. (2011) Intentions to Use Social Media in Organizing and Taking Vacation Trips. Computer in Human Behavior, 27, 640-654. https://doi.org/10.1016/j.chb.2010.05.022

[9] Sparks, B.A. and Browning, V. (2011) The Impact of Online Reviews on Hotel Booking Intentions and Perception of Trust. Tourism Management, 32, 1310-1323. https://doi.org/10.1016/j.tourman.2010.12.011

[10] Nixon, L., Popova, A. and Onder, I. (2017) How Instagram Influences Visual Destination Image: A Case Study of Jordan and Costa Rica. ENTER2017 eTourism conference, Rome. Italy.

[11] Bernkopf, D. and Nixon, L. (2019) The Impact of Visual Social Media on the Projected Image of a Destination: The Case of Mexico City on Instagram. In: Information and Communication Technologies in Tourism, Springer International Publishing, Nicosia, Cyprus, 145-157. https://doi.org/10.1007/978-3-030-05940-8_12

[12] Fakeye, P.C. and Crompton, J.L. (1991) Image Differences between Prospective, First-Time, and Repeat Visitors to the Lower Rio Grande Valley. Journal of Travel Research, 30, 10-16. https://doi.org/10.1177/004728759103000202

[13] Embacher, J. and Buttle, F. (1989) A Repertory Grid Analysis of Austria's Image as a Summer Vacation Destination. Journal of Travel Research, 3, 3-23. https://doi.org/10.1177/004728758902700302

[14] Reynolds, W.H. (1965) The Role of the Consumer in Image Building. California Management Review, 7, 69-75. https://doi.org/10.2307/41165634

[15] Gartner, W.C. (1994) Image Formation Process. Journal of Travel and Tourism Marketing, 2, 191-216. https://doi.org/10.1300/J073v02n02_12

[16] Maroofi, F. and Hassani, S.R. (2017) Relationship between Destination Image, Tourist Satisfaction, and Destination Loyalty. In: Ray, N., Das, D.K. and Kumar, R., Ed., Tourism Marketing. A Strategic Approach, Apple Academic Press, town, NJ, 25-56. https://doi.org/10.1201/9781315365862-3

[17] Machado, L. (2010) Does Destination Image Influence the Length of Stay in a Tourism Destination? Background Arguments. Tourism Economics, 16, 443-456. https://doi.org/10.5367/000000010791305554

[18] Dwivedi, M. (2009) Online Destination Image of India : A Consumer Based Pers- 
pective. International Journal of Contemporary Hospitality Management, 21, 226-232. https://doi.org/10.1108/09596110910935714

[19] Li, X., Pan, B., Zhang, L. and Smith, W.W. (2009) The Effect of Online Information Search on Image Development: Insights From a Mixed-Methods Study. Journal of Travel Research, 48, 45-57. https://doi.org/10.1177/0047287508328659

[20] Kim, S.E., Lee, K.Y., Shin, S.I. and Yang, S.B. (2017) Effects of Tourism Information Quality in Social Media on Destination Image Formation : The Case of Sina Weibo. Information and Management, 54, 687-702. https://doi.org/10.1016/j.im.2017.02.009

[21] Muhoho-Minni, P. and Lubbe, B.A. (2017) The Role of the Media in Constructing a Destination Image : The Kenya Experience. Communication, 43, 58-79.

https://doi.org/10.1080/02500167.2016.1226915

[22] Nelson, V. (2005) Representation and Images of People, Place and Nature in Grenada's Tourism. Geografiska Annaler, 87, 131-143. https://doi.org/10.1111/j.0435-3684.2005.00187.x

[23] Lian, T. and Yu, C. (2017) Representation of Online Image of Tourist Destination: A Content Analysis of Huangshan. Asia Pacific Journal of Tourism Research, 22, 1063-1082. https://doi.org/10.1080/10941665.2017.1368678

[24] Ahmed, M.J. and Akbaba, A. (2018) The Potential of Halal Tourism in Ethiopia: Opportunities, Challenges and Prospects. International Journal of Contemporary Tourism Research, 1, 13-22. https://doi.org/10.30625/ijctr.397499

[25] MasterCard and Cresent Rating (2019) Global Muslim Travel Index.

[26] The National Development Planning Board (2018) Masterplan Ekonomi Syariah Indonesia 2019-2024.

[27] Mackay, K.J. and Couldwell, C.M. (2004) Using Visitor-Employed Photography to Investigate Destination Image. Journal of Travel Research, 42, 390-396. https://doi.org/10.1177/0047287504263035

[28] Taufiqqurrachman (2019) Human Value Manifest in Instagram: A Visual Content Analysis of DMO Photography. New Media and Mass Communication, 80, 63-76.

[29] Jenkins, O. (2003) Photography and Travel Brochures: The Circle of Representation. An International Journal of Tourism Space, Place and Environment, 5, 305-328. https://doi.org/10.1080/14616680309715

[30] Stepchenkova, S. and Zhan, F. (2013) Visual Destination Images of Peru: Comparative Content Analysis of DMO and User-Generated Photography. Tourism Management, 36, 590-601. https://doi.org/10.1016/j.tourman.2012.08.006

[31] Akyol, M. and Kilinc, O. (2014) Internet and Halal Tourism Marketing. Turkish Studies, 9, 171-186. https://doi.org/10.7827/TurkishStudies.7278

[32] Suradin, M. (2018) Halal Tourism Promotion in Indonesia: An Analysis on Official Destination Websites. Journal of Indonesian Tourism and Development Studies, 6, 143-158. https://doi.org/10.21776/ub.jitode.2018.006.03.01

[33] Kavaratzis, M. and Ashworth, G.J. (2006) City branding: An Effective Assertion of Identity or a Transitory Marketing Trick? Place Branding and Public Diplomacy, 2, 183-194. https://doi.org/10.1057/palgrave.pb.5990056

[34] Gallarza, M.G., Saura, I.G. and Garcia, H.C. (2002) Destination Image: Towards a Conceptual Framework. Annals of Tourism Research, 29, 56-78. https://doi.org/10.1016/S0160-7383(01)00031-7

[35] Echtner, C.M. and Ritchie, J.R.B. (1991) The Meaning and Measurement of Destination Image. The Journal of Tourism Studies, 2, 2-12. 
[36] Crompton, J.L. (1979) An Assessment of the Image of Mexico as a Vacation Destination and the Influence of Geographical Location Upon That Image. Journal of Travel Research, 17, 18-23. https://doi.org/10.1177/004728757901700404

[37] Hunt, J.D. (1975) Image as a Factor in Tourism Development. Journal of Travel Research, 13, 1-7. https://doi.org/10.1177/004728757501300301

[38] Calantone, J.R., Benedetto, A., Hakam, A. and Bojanic, C.D (1989) Multiple Multinational Tourism Positioning Using Correspondence Analysis. Journal of Travel Research, 28, 25-32. https://doi.org/10.1177/004728758902800207

[39] Baloglu, S. and McCleary, K.W. (1999) A Model of Destination Image Formation. Annals of Tourism Research, 26, 868-897. https://doi.org/10.1016/S0160-7383(99)00030-4

[40] Stepchenkova, S. and Morrison, A.M. (2008) Russia's Destination Image among American Pleasure Travelers: Revisiting Echtner and Ritchie. Tourism Management, 29, 548-560. https://doi.org/10.1016/j.tourman.2007.06.003

[41] Martin, H.S and del Bosque, R. (2008) Exploring The Cognitive-Affective Nature of Destination Image and The Role of Psychological Factors in Its Formation. Tourism Management, 29, 263-277. https://doi.org/10.1016/j.tourman.2007.03.012

[42] Dann, G.M. (1996) Tourists' Images of a Destination: An Alternative Analysis. Journal of Travel and Tourism Marketing, 5, 41-55. https://doi.org/10.1300/J073v05n01_04

[43] Pike, S. and Ryan, C. (2004) Destination Positioning Analysis through a Comparison of Cognitive, Affective, and Conative Perceptions. Journal of Travel Research, 42, 333-342. https://doi.org/10.1177/0047287504263029

[44] Agapito, D., Oom do Valle, P. and da Costa Mendes, J. (2013) The Cognitive-Affective-Conative Model of Destination Image: A Confirmatory Analysis. Journal of Travel and Tourism Marketing, 30, 471-481. https://doi.org/10.1080/10548408.2013.803393

[45] Esper, F.S. and Rateike, J.Á. (2010) Tourism Destination Image and Motivations: The Spanish Perspective of Mexico. Journal of Travel and Tourism Marketing, 27, 349-360. https://doi.org/10.1080/10548408.2010.481567

[46] Beerli, A. and Martín, J.D. (2004) Factors Influencing Destination Image. Annals of Tourism Research, 31, 657-681. https://doi.org/10.1016/j.annals.2004.01.010

[47] Fodness, D. and Murray, B. (1998) A Typology of Tourist Information Search Strategies. Journal of Travel Research, 37, 108-119. https://doi.org/10.1177/004728759803700202

[48] Gunn, C.A. (1972) Vacationscape: Designing Tourist Regions. Bureau of Business Research, University of Texas, Austin, TX. https://doi.org/10.1177/004728757301100306

[49] Selby, M. and Morgan, N.J. (1996) Reconstruing Place Image: A Case Study of Its Role in Destination Market Research. Tourism Management, 17, 287-294. https://doi.org/10.1016/0261-5177(96)00020-9

[50] Gearing, C.E., Swart, W.W. and Var, T. (1974) Establishing a Measure of Touristic Attractiveness. Journal of Travel Research, 12, 1-8. https://doi.org/10.1177/004728757401200401

[51] Pearce, P.L. (1982) Perceived Changes in Holiday Destinations. Annals of Tourism Research, 9, 145-164. https://doi.org/10.1016/0160-7383(82)90044-5

[52] Dilley, R. (1986) Tourist Brochures and Tourist Images. The Canadian Geographer, 30, 59-65. https://doi.org/10.1111/j.1541-0064.1986.tb01026.x 
[53] Gartner, W.C. (1989) Tourism Image: Attribute Measurement of State Tourism Products Using Multidimensional Scaling Techniques. Journal of Travel Research, 28, 16-20. https://doi.org/10.1177/004728758902800205

[54] Mercille, J. (2005) Media Effect on Image: The Case of Tibet. Annals of Tourism Research, 32, 1039-1055. https://doi.org/10.1016/j.annals.2005.02.001

[55] Young, A.F., Young, R. and Young, A.F. (2008) Measuring the Effects of Film and Television on Tourism to Screen Locations: A Theoretical and Empirical Perspective. Journal of Travel and Tourism Marketing, 24, 195-212. https://doi.org/10.1080/10548400802092742

[56] Hahm, J. and Wang, Y. (2011) Film-Induced Tourism as a Vehicle for Destination Marketing: Is It Worth the Efforts? Journal of Travel and Tourism Marketing, 28, 165-179. https://doi.org/10.1080/10548408.2011.546209

[57] Wang, D., Chan, H.L. and Pan, S. (2014) The Impacts of Mass Media on Organic Destination Image: A Case Study of Singapore. Asia Pacific Journal of Tourism Research, 20, 860-874.

[58] Aghaei, S., Nematbakhsh, M.A. and Farsani, H.K. (2012) Evolution of the WWW: From Web 1.0 to Web 4.0. International Journal of Web and Semantic Technology, 3, 1-10. https://doi.org/10.5121/ijwest.2012.3101

[59] Akehurst, G. (2009) User Generated Content: The Use of Blogs For Tourism Organisations And Tourism Consumers. Service Business, 3, 51-61.

https://doi.org/10.1007/s11628-008-0054-2

[60] Yoo, K.H. and Gretzel, U. (2010) Antecedents and Impacts of Trust in Travel-Related Consumer-Generated Media. Information Technology and Tourism, 12, 139-152. https://doi.org/10.3727/109830510X12887971002701

[61] Ayeh, J.K., Au, N. and Law, R. (2013) Predicting the Intention to Use Consumer-Generated Media for Travel Planning. Tourism Management, 35, 132-143. https://doi.org/10.1016/j.tourman.2012.06.010

[62] Chan, N.L. and Guillet, B.D. (2011) Investigation of Social Media Marketing: How Does the Hotel Industry in Hong Kong Perform in Marketing on Social Media Websites? Journal of Travel and Tourism Marketing, 28, 345-368. https://doi.org/10.1080/10548408.2011.571571

[63] Pavlović, D.K. and Belullo, A. (2007) Internet-An Agent of Tourism Destination Image Formation: Content and Correspondence Analysis of Istria Travel Related Websistes. International Conference on Global Challenges for Competitiveness. Business and Government Perspective: Proceeding, Pula-Croatia, 541-556

[64] Battour, M. and Ismail, M.N. (2016) Halal Tourism: Concepts, Practises, Challenges and Future. Tourism Management Perspectives, 19, 150-154. https://doi.org/10.1016/j.tmp.2015.12.008

[65] (2006) Dictionary of Leisure, Travel, and Tourism. A and C Black, London.

[66] Decrop, A. (2007) The Influence of Message Format on the Effectiveness of Print Advertisements for Tourism Destinations. International Journal of Advertising: The Review of Marketing Communications, 26, 505-525. https://doi.org/10.1080/02650487.2007.11073030

[67] Schellhorn, M.S. and Perkins, H.C. (2004) The Stuff of Which Dreams Are Made: Representations of the South Sea in German-Language Tourist Brochures. Current Issues in Tourism, 7, 95-133. https://doi.org/10.1080/13683500408667975

[68] Neuendorf, K.A. (2002) The Content Analysis Guidebook. Sage, Thousand Oaks, CA. 
[69] Bell, P. (2001) Content Analysis of Visual Images. In: Van Leeuwen, T. and Jewitt, C., Eds., The Handbook of Visual Analysis, Sage, London, 10-34. https://doi.org/10.4135/9780857020062.n2

[70] Ingold, T. (1994) Introduction to Culture. In: Ingold, Ed., Companion Encyclopedia of Antropology, Routledge, London, 329-349.

[71] Wolburg, J.M. and Kim, H. (2000) Advertising and Culture: Variations on the Theme of Individualism in Korean and American Magazine Advertising. World Communication, 29, 63-71.

[72] Zhang, J. and Shavitt, S. (2003) Cultural Values in Advertisements to the Chinese X-Generation-Promoting Modernity and Individualism. Journal of Advertising, 32, 23-33. https://doi.org/10.1080/00913367.2003.10639047

[73] Hsu, S.Y. and Barker, G.G. (2013) Individualism and Collectivism in Chinese and American Television Advertising. The International Communication Gazette, 75, 695-714. https://doi.org/10.1177/1748048513482543

[74] Mok, C. and Defranco, A.L. (2008) Chinese Cultural Values: Their Implications for Travel and Tourism Marketing. Journal of Travel and Tourism Marketing, 8, 99-114. https://doi.org/10.1300/J073v08n02_07

[75] Torelli, C.J., Ozsomer, A., Carvalho, S.W., Keh, H.T. and Maehle, N. (2012) Brand Concepts as Representations of Human Values: Do Cultural Congruity and Compatibility Between Values Matter? Journal of Marketing, 76, 92-108. https://doi.org/10.1509/jm.10.0400

[76] Saji, B.S., Vij, M. and Kabiraj, S. (2015) Selection of Tourism Destination as a Representation of Human Values. Business Perspective and Research, 3, 95-108. https://doi.org/10.1177/2278533715578554

[77] Battour, M., Battor, M. and Bhatti, M.A. (2013) Islamic Attributes of Destination: Construct Development and Measurement Validation, and Their Impact on Tourist Satisfaction. International Journal of Tourism Research, 16, 556-564. https://doi.org/10.1002/jtr.1947

[78] El-Gohary, H. (2016) Halal Tourism, Is It Really Halal? Tourism Management Perspectives, 19, 124-130. https://doi.org/10.1016/j.tmp.2015.12.013

[79] Isa, S.M., Chin, P.N. and Mohammad, N.U. (2018) Muslim Tourist Perceived Value: A Study on Malaysia Halal Tourism. Journal of Islamic Marketing, 9, 402-420. https://doi.org/10.1108/JIMA-11-2016-0083

[80] Hanzaee, K.H. and Ramezani, M. (2011) Intention to Halal Products in the World Markets. Interdisciplinary Journal of Research in Business, 1, 1-7.

[81] Puntoni, S., Schroeder, J.E. and Ritson, M. (2010) Meaning Matters: Polysemy in Advertising. Melbourne Business School, 1-40. http://works.bepress.com/ritson/5

[82] Rodrigues, R.C. (2013) Photographic Image: Thematization of Its Discourses. Journal of Signal and Information Processing, 4, 414-422. https://doi.org/10.4236/jsip.2013.44053

[83] Rose, G. (2001) Visual Methodologies. An Introduction to the Interpretation of Visual Materials. Sage Publications, London, England.

[84] Haahti, A.J. (1986) Findland's Competitive Position as a Destination. Annals of Tourism Research, 13, 11-35. https://doi.org/10.1016/0160-7383(86)90055-1

[85] Hu, Y. and Ritchie, J.R.B. (1993) Measuring Destination Attractiveness: A Contextual Approach. Journal of Travel Research, 32, 25-34. https://doi.org/10.1177/004728759303200204

[86] Milman, A. and Pizam, A. (1995) The Role of Awareness and Familiarity with a 
Destination: The Central Florida Case. Journal of Travel Research, 33, 21-27. https://doi.org/10.1177/004728759503300304

[87] Kim, H.-B. (1998) Perceived Attractiveness of Korean Destinations. Annals of Tourism Research, 25, 340-361. https://doi.org/10.1016/S0160-7383(98)00007-3

[88] Nummedal, M. and Hall, C.M. (2006) Local Food in Tourism: An Investigation of the New Zealand South Island's Bed and Breakfast Sector's Use and Perception of Local Food. Tourism Review International, 9, 365-378. https://doi.org/10.3727/154427206776330571

[89] Du Rand, G.E., Heath, E. and Alberts, N. (2003) The Role Of Local And Regional Food In Destination Marketing. Journal of Travel and Tourism Marketing, 14, 97-112. https://doi.org/10.1300/J073v14n03_06

[90] Kim, Y.H., Yuan, J., Goh, B.K. and Antun, J.M. (2009) Web marketing in Food Tourism: A Content Analysis of Web Sites in West Texas. Journal of Culinary Science and Technology, 7, 52-54. https://doi.org/10.1080/15428050902788352 